\title{
Jahrestagung der Deutschen, Österreichischen und Schweizerischen \\ Gesellschaften für Hämatologie und Medizinische Onkologie
}

\author{
1.-4. Oktober 2021, Berlin
}

\section{ABSTRACTS}

Herausgeber

Prof. Dr. med. Andreas Mackensen, Erlangen 


\section{Kongresspräsident}

Wissenschaftliches Team

\author{
Abstract-Gutachter
}

Prof. Dr. med. Andreas Mackensen, Erlangen

Prof. Dr. med. Dimitrios Mougiakakos

Prof. Dr. med. Stefan Krause

Maria Habermann

Liane Bischoff-Ziebell

Stefan Paul Aebi, Bernd Alt-Epping, Elizabeth Andritsch, Caroline Arber, Dirk Arnold Stefan Balabanov, Claudia Baldus, Marija Balic, Mario Bargetzi, Florian Bassermann Sebastian Bauer, Thomas Bauernhofer, Walter Baumann, Dora Beke-Niedersüß Wolfgang Bethge, Jörg Beyer, Stefan Bielack, Mascha Binder, Carsten Bokemeyer Markus Maximilian Borner, Martin Bornhäuser, Thomas Brodowicz, Peter Brossart Monika Brüggemann, Tim Henrik Brümmendorf, Lars Bullinger, Andreas Burchert Christian Buske, Antonia Busse, Holger Cario, Richard Cathomas, Thomas Cerny Björn Chapuy, Oliver A. Cornely, Maike de Wit, Uta Dirksen, Martin Dreyling Christoph Driessen, Matthias Edinger, Alexander Egle, Barbara Eichhorst Wolfgang Eisterer, Monika Engelhardt, Sebastian Fetscher, Jürgen Finke Thomas Fischer, Lukas Flatz, Gunnar Folprecht, Ralph Fritsch, Stefan Fröhling Martin Fromm, Martin Früh, Thorsten Füreder, Alexander Gaiger, Klaus Geissler Armin Gerger, Ulrich Germing, Silke Gillessen, Heinz Gisslinger, Jeroen S. Goede Nicola Gökbuget, Hartmut Goldschmidt, Katharina Götze, Hildegard Greinix Frank Griesinger, Martin Grießhammer, Birgit Grünberger, Matthias Gründel Viktor Grünwald, Detlef Haase, Jessica Hassel, Florian H. Heidel, Volker Heinemann Daniel Heintel, Viola Heinzelmann, Matthias Hellberg-Naegele, Marco Herling Wolfgang Herr, Viviane Hess, Pia Heußner, Wolfgang Hilbe, Inken Hilgendorf Felicitas Hitz, Andreas Hochhaus, Anette Hoferer, Wolf-Karsten Hofmann Christoph Höller, Katharina Holstein, Karel Horvath, Jutta Hübner, Michael Hudecek Gerald Illerhaus, Ulrich Jäger, Daniela Jahn-Kuch, Christian Junghanß Eva-Maria Kalusche-Bontemps, Stefan Kasper-Virchow, Johann Kaufmann Ulrich Keilholz, Ulrich Keller, Barbara Kiesewetter, Michael Klein, Paul Knöbl Dieter Köberle, Claus-Henning Köhne, Antje Koller, Steffen Koschmieder Angela Krackhardt, Michael Krainer, Stefan Krause, Michael Krauthammer Florian Langer, Philipp Le Coutre, Claudia Lengerke, Georg Lenz, Lynn Leppla Anne Letsch, Lars H. Lindner, Hartmut Link, Sonja Loges, Anja Lorch, Florian Lordick Michael Lübbert, Diana Lüftner, Sigrid Machherndl-Spandl, Andreas Mackensen Markus Manz, Christine Marosi, Georg Maschmeyer, Norbert Meidenbauer Johannes Meran, Andreas Michalsen, Dominik Modest, Dimitrios Mougiakakos Fabian Müller, Carsten Müller-Tidow, II-Kang Na, Ralph Naumann, Karen Nestor Andreas Neubauer, Urban Novak, Karin Oechsle, Thomas Oellerich, Helmut Oettle Jens Panse, Jakob Passweg, Andrea Petermann-Meyer, Christina Peters Andreas Petzer, Martin Pichler, Andreas Pircher, Matthias Preusser, Milo Puhan Tobias Pukrop, Leo Rasche, Gunnar Rätsch, Daniel Rauch, Christoph Reinhardt Andreas Reiter, Roland Repp, Christoph Röllig, Matthias Rostock, Patrick Roth Sacha Rothschild, Philippe Schafhausen, Urs Schanz, Jan-Dirk Schildmann Georgia Schilling, Manuela Schmidinger, Silke Schmidt, Clemens A. Schmitt Hubert Schrezenmeier, Martin Schuler, Ulrich Schuler, Ulf Seifart, Hans-Jörg Senn Hubert Serve, Marco Siano, Marianne Sinn, Alexander Stein, Stephan Stilgenbauer Sebastian Stintzing, Jan-Dirk Studt, Georg Stüssi, Marion Subklewe, Hans Tesch Alexandre Theocharides, Harald Titzer, Martin Trepel, Lorenz Trümper, Andreas Viardot Gunhild von Amsberg, Marie von Lilienfeld-Toal, Bastian von Tresckow Dirk Thomas Waldschmidt, Cornelius Waller, Ulrich Wedding, Lukas Weiss Florian Weißinger, Ansgar Weltermann, Clemens-Martin Wendtner, Andreas Wicki Wolfgang Willenbacher, Eva Winkler, Claudia Witt, Dominik Wolf, Ewald Wöll Bernhard Wörmann, Thorsten Zenz 


\section{Disclosure Statement Guest Editor The editor declares no conflict of interest.}

\section{S. Karger}

Medical and Scientific Publishers Basel · Freiburg · Hartford · Oxford · Bangkok $\cdot$ Dubai $\cdot$ Kuala Lumpur .

Melbourne $\cdot$ Mexico City

Moscow $\cdot$ New Delhi $\cdot$ Paris

Shanghai $\cdot$ Tokyo
Disclaimer

The statements, opinions and data contained in this publication are solely those of the individual authors and contributors and not of the publisher and the editor(s). The appearance of advertisements in the journal is not a warranty, endorsement, or approval of the products or services advertised or of their effectiveness, quality or safety. The publisher and the editor(s) disclaim responsibility for any injury to persons or property resulting from any ideas, methods, instructions or products referred to in the content or advertisements.

Drug Dosage

The authors and the publisher have exerted every effort to ensure that drug selection and dosage set forth in this text are in accord with current recommendations and practice at the time of publication. However, in view of ongoing research, changes in government regulations, and the constant flow of information relating to drug therapy and drug reactions, the reader is urged to check the package insert for each drug for any change in indications and dosage and for added warnings and precauin indications and dosage and for added warnings and precau-
tions. This is particularly important when the recommended agent is a new and/or infrequently employed drug.
All rights reserved.

No part of this publication may be translated into other languages, reproduced or utilized in any form or by any means, electronic or mechanical, including photocopying, recording microcopying, or by any information storage and retrieval system, without permission in writing from the publisher or in the case of photocopying, direct payment of a specified fee to the Copyright Clearance Center (see 'General Information').

(c) Copyright 2021 by S. Karger AG,

P.O. Box, CH-4009 Basel (Switzerland)

Printed on acid-free and non-aging paper (ISO 9706)

ISBN 978-3-318-06712-5

e-ISBN 978-3-318-06713-2 
